\title{
Identifikasi Mutasi DNA Daerah HV1 dan HV2 D-Loop Mitokondria dari Pasien Diabetes Mellitus Tipe 2 (DMT2)
}

\section{Identification of HV1 and HV2 D-Loop Regional Mitochondrial DNA Mutations from Type 2 Diabetes Mellitus Patients (DMT2)}

\author{
Rina Budi Satiyarti ${ }^{1}$, Nenden Dwi Sajati ${ }^{2}$, dan Rahmaniar Mulyani ${ }^{2}$ \\ ${ }^{1}$ Universitas Islam Negeri Raden Intan Lampung \\ ${ }^{2}$ Universitas Jenderal Achmad Yani \\ *E-mail: rinabudisatiyarti@ radenintan.ac.id
}

DOI : https://doi.org/10.26874/jkk.v3i1.41

Received: 6 Dec 2019, Revised: 31 May 2020, Accepted: 31 May 2020, Online: 31 May 2020

\begin{abstract}
Abstrak
Diabetes mellitus tipe 2 (DMT2) adalah penyakit yang disebabkan oleh penurunan jumlan insulin oleh sel beta pankreas atau kerja insulin yang tidak efektif. Penyakit ini terakumulasi dari gaya hidup tidak sehat atau karena keturunan. Penyebab DMT2 dapat dikaitkan dengan disfungsi DNA mitokondria (mtDNA) yang disebabkan oleh penumpukkan mutasi. Daerah D-loop merupakan bagian dari mtDNA yang memiliki dua daerah yaitu HV1 dan HV2 dengan laju mutasi paling tinggi. Maka, dilakukan penelitian untuk mengidentifikasi mutasi d-loop daerah HV1 dan HV2 untuk mencari mutasi baru yang berkaitan dengan DMT2. Tahapan yang dilakukan meliputi isolasi mtDNA, amplifikasi fragmen HV1 dan HV2 dengan teknik Polymerase Chain Reaction (PCR), visualisasi hasil PCR dengan elektroforesis gel agarosa, penentuan urutan nukleotida daerah HV1 dan HV2 mtDNA, dan analisis hasil sekuensing. Berdasarkan hasil analisis dari perbandingan antara urutan nukleotida sampel dengan revised Cambridge Reference Sequence (rCRS), ditemukan mutasi 16189T >C pada sampel DM02; DM03, dan mutasi 16223C > T pada sampel DM02; DM03; DM04 daerah HV1 D-loop mtDNA, juga mutasi 73A>G pada sampel DM02; DM03; DM04 daerah HV2 D-loop mtDNA. Hasil analisis pada MITOMAP menunjukkan bahwa mutasi $16189 \mathrm{~T}>\mathrm{C}$ tercatat sebagai mutasi yang terdapat pada diabetes, mutasi $16223 \mathrm{C}>\mathrm{T}$ tidak terkait dengan penyakit apapun, dan mutasi $73 \mathrm{~A}>\mathrm{G}$ terdapat pada penuaan sel otak.
\end{abstract}

Kata Kunci: Diabetes mellitus tipe 2 (T2DM), mitokondria DNA, D-loop, mutasi, MITOMAP.

\begin{abstract}
Type 2 diabetic mellitus (T2DM) is a disease which is caused by insufficient insulin amount or ineffective insulin action to breakdown glucose. This disease is an accumulation from unhealthy lifestyle and for some people, they inherit T2DM from their parents. T2DM is related to mitochondria DNA (mtDNA) dysfunction due to DNA mutation. D-loop area is a control region in mtDNA, which is has a highest rate of DNA mutation. It divided into two areas, $H V 1$ and HV2. Therefore, it need a lot of information to study T2DM genetically. There three stages in this research, D-loop DNA fragment amplification from four blood samples, namely DM01, DM02, DM03, and DM04. Sequence determination of D-loop fragment, and mutation analysis. D-loop fragment amplification given 0,9 kilobase (kb) in size. Sequence DNA determination showed only three samples were successful to be sequenced (DM02, DM03, and DM04). Alignment analysis of D-loop fragment and reference (rRCS) show three substitution mutations, there are 16189T>C occur in DM02 and DM03, 16233C>T occur in DM02, DM03, DM04. Both mutation located in HV1 area. While 73A $>G$ which located in HV2 occur in DMO2, DM03, and DM04. 16189T>C in MITOMAP was related to diabetic, while 16233C >T was not related to any disease, while $73 A>G$ was related to brain death cell.
\end{abstract}

Keywords: Type 2 diabetic mellitus (T2DM), DNA mitochondria, D-loop, mutation, MITOMAP 


\section{Pendahuluan}

Diabetes melitus (DM) dapat didefinisikan sebagai suatu penyakit gangguan metabolisme yang ditandai dengan peningkatan kadar gula darah yang dapat diakibatkan oleh kerja hormon insulin yang tidak optimal (insufisiensi insulin). Insufisiensi fungsi insulin dapat disebabkan oleh gangguan produksi insulin oleh sel-sel beta Langerhans kelenjar pankreas, atau disebabkan oleh kurang responsifnya sel-sel tubuh terhadap insulin [1]. Diabetes mellitus dibagi menjadi dua jenis yaitu diabetes mellitus tipe 1 dan 2, diabetes khusus lainnya, dan diabetes kehamilan [2].

Diabetes melitus Tipe-2 (DMT2) disebabkan oleh faktor pola gaya hidup dan faktor genetik. Beberapa faktor pola gaya hidup diketahui berpengaruh besar pada pembentukan DMT2. Diantaranya adalah fisik yang tidak aktif bergerak, merokok dan konsumsi alkohol yang berlebih [3]. Penyakit diabetes melitus tipe-2 (DMT2) ada hubungannya dengan mitokondria. Mitokondria berpengaruh dalam sekresi insulin dari sel $\beta$ pankreas. Sekresi insulin oleh sel $\beta$ pankreas sangat bergantung pada sintesis adenosin trifosfat (ATP) melalui fosforilasi oksidatif mitokondria [4]. Beberapa penelitian telah menjelaskan hubungan mutasi DNA pada mitokondria dengan penyakit DMT2 ini, yaitu pada daerah gen tRNA ${ }^{\text {leu }}$, gen ATP6 dan ATP8 [5-7]. Daerah pada mtDNA yang mengalami laju mutasi paling tinggi dan menjadi fokus studi dalam pemeriksaan keterkaitan mutasi genetik dan berbagai jenis penyakit adalah daeah D-loop [8].

Daerah D-loop merupakan bagian dari mtDNA yang memiliki dua daerah dengan laju mutasi dan tingkat polimorfisme paling tinggi, yaitu daerah Hipervariabel I (HVI) dan Hipervariabel II (HVII) [9]. Tingginya laju mutasi mtDNA disebabkan karena DNA polymerase $\gamma$ yang digunakan pada proses replikasi mtDNA tidak memiliki proffreading yang dapat mengoreksi kesalahan-kesalahan selama proses replikasi. Laju mutasi mtDNA 5-10 kali lebih tinggi dibanding laju mutasi DNA inti (nDNA) [8].

Penelitian mengenai daerah D-loop mtDNA pada penderita diabetes juga telah dilakukan oleh Puspitaningrum dkk, (2014) pada daerah HVI Dloop mtDNA dari 16 pasien penderita DMT2. Sebanyak 30 daerah mutasi ditemukan dalam 442pb (16.024-16.365). Daerah dengan frekuensi mutasi tertinggi ditemukan pada T16296C (66,6\%), C16126T (61,1\%), C16223T (55,5\%), T16294C (55,5\%). Penelitian lain mengenai mutasi penyebab DMT2 pada daerah selain Dloop yaitu daerah Gen tRNA ${ }^{\text {leu }}$ mtDNA telah dilakukan oleh Maksum et al. (2010) pada 101 pasien penderita DMT2 isolat Bandung yaitu di RS Ciumbuleuit, RS Pindad, Laboratorium Klinik Prodia, dan Laboratorium Klinik Pramita [6].

Urutan nukleotida pada daerah D-loop mtDNA pada setiap manusia sangat bervariasi, sehingga perlu dilakukan penelitian mengenai mutasi pada daerah D-loop mtDNA untuk mengetahui mutasi selain dari mutasi yang telah ditemukan pada penelitian sebelumnya. Sehingga, perlu dilakukan penelitian mengenai variasi basa nukleotida pada daerah HVI dan HVII D-loop mtDNA pada penderita DMT2 di wilayah Jawa Barat.

\section{Metode Penelitian \\ 2.1 Bahan}

Sampel darah diperoleh dari empat penderita Diabetes Melitus Tipe-2 dilakukan di RS Dustira Cimahi. Rentang usia penderita adalah 60-80 tahun, dan terdiri dari tiga wanita dan satu pria. Buffer lisis 10x (50 mM Tris- $\mathrm{HCl} \mathrm{pH} 8,1 \mathrm{mM}$ EDTA pH 8, dan 0,5\% Tween-20), enzim proteinase $\mathrm{K} 200 \mu \mathrm{g} / \mathrm{mL}$ dan $\mathrm{ddH}_{2} \mathrm{O}$ steril. primer M1 (5'-CACCATTAGCACCCAAAGCT-3') 20 $\mathrm{pmol} / \mu \mathrm{L}, \quad$ primer $\mathrm{HV} 2 \mathrm{R}$ CTGTTAAAAGTGCATACCGCC-3') 20 $\mathrm{pmol} / \mu \mathrm{L}$, DreamTaq Green PCR Master Mix (2X) (DreamTaq DNA polimerase, 2X buffer DreamTaq Green, 0,4 mM dNTP, dan $4 \mathrm{mM}$ $\mathrm{MgCl}_{2}$ ), dan NFW (Nuclease-Free Water), agarosa, TAE 1x (40 mM Tris-asetat dan $1 \mathrm{mM}$ EDTA pH 8,0); loading buffer (sukrosa 50\% dan $0,1 \%$ bromfenol biru $\mathrm{pH} 8,0$ ); NFW; dan gel red. Penanda (marker) GeneRuler ${ }^{T M} 1$ kb DNA Ladder.

\subsection{Tahapan Penelitian}

Sampel darah dicuci sebanyak tiga kali menggunakan buffer TE 1x, hingga sel darah terpisahkan dari plasma darah. DNA template diperoleh dari hasil lisis sel darah. Sel darah dilisis menggunakan buffer lisis (Bufer Tris-Cl, EDTA, Tween 80, Proteinase K). Campuran kemudian dipanaskan selama 60 menit pada suhu $50{ }^{\circ} \mathrm{C}$, dan dipisahkan melalui sentrifugasi $12000 \mathrm{rpm}$. Kondisi PCR yang dilakukan terdiri dari 30 siklus, terdiri dari $94^{\circ} \mathrm{C}\left(60\right.$ detik), $50^{\circ} \mathrm{C}$ (60 detik), dan $72^{\circ} \mathrm{C}$ (90 detik). Primer yang digunakan adalah 
M1 5'-CACCATTAGCACCCAAAGCT-3' dan HV2R 5'-CTGTTAAAAGTGCATACCGCC-3'. Sekuensing dilakukan oleh Macrogen Inc. Analisis variasi DNA mitokondria dilakukan menggunakan perangkat lunak DNA STAR.

\section{Hasil dan Diskusi}

Fragmen DNA mitokondria yang mengapit daerah HV1 dan HVII D-loop mitokondria dari empat sampel berhasil diamplifikasi dengan ukuran 0,9 kb-1 kb (Gambar 1). Fragmen ini didapatkan dari hasil optimasi suhu penempelan primer, yaitu $49,7^{\circ} \mathrm{C}$. Adapun Kontrol positif dari keempat sampel adalah templat DNA dari manusia yang tidak terdiagnosa DMT tipe II.

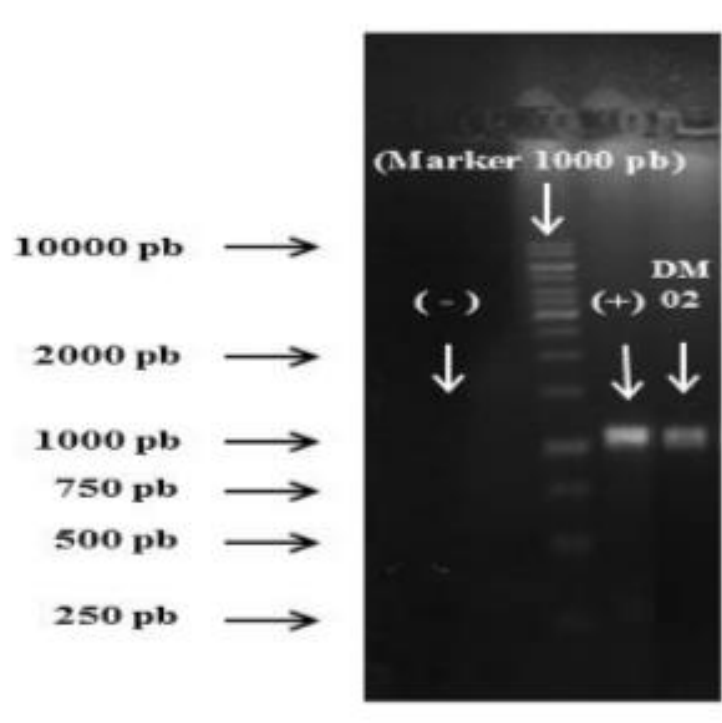

(a)

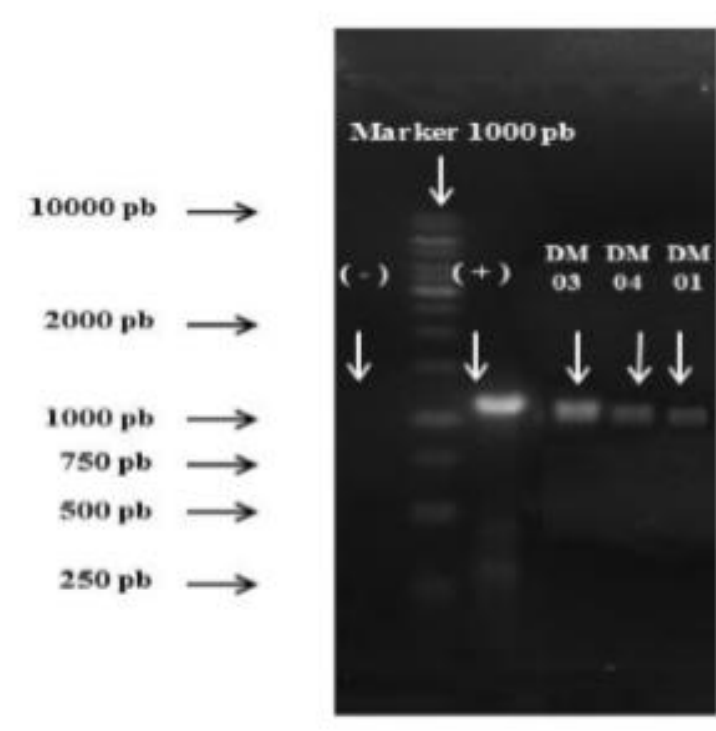

(b)

Gambar 1. (a) hasil amplifikasi fragmen DNA sampel DM2, (b) hasil amplifikasi fragmen DNA sampel DM1, DM3, dan DM4.

Amplikon yang di urutkan nukleotidanya sebesar 6-12 $\mu \mathrm{g} / \mathrm{L}$. Amplikon ini ternyata menghasilkan uraian nukleotida sepanjang kurang lebih 800 pasang basa. Urutan nukleotida ini di analisa variasi basa nukleotidanya, dengan membandingkan urutan sampel dan urutan kontrol positif.

Hasil analisa urutan nukleotida menunjukkan bahwa hanya tiga sampel dari empat sampel yang dapat di urutkan, yaitu DM2, DM3, dan DM4. Ketiga sampel tersebut disejajarkan urutannya dengan urutan basa daerah HVI dan HV2 D-loop mitokondria reverse Cambridge reference sequence (rCRS). Hasil dari ketiga pensejajaran tersebut memperlihatkan mutasi titik yag merupakan mutasi substitusi basa nukelotida 16189T $>\mathrm{C}, 16223 \mathrm{C}>\mathrm{T}$ pada daerah HVI, dan 73A>G pada daerah HVII (Gambar 2). Diketahui bahwa mutasi $16189 \mathrm{~T}>\mathrm{C}$ merupakan mutasi pada daerah HVI yang terjadi ketika seseorang mengalami Diabetes [10]. Mutasi tersebut terdapat pada sampel DM2 dan DM3. Sedangkan, mutasi $16223 \mathrm{C}>\mathrm{T}$ terjadi di semua sampel. Mutasi ini terdapat juga pada daerah HVI dari beberapa sampel mtDNA penderita DMT2 [11].

Hasil analisis MITOMAP menunjukkan bahwa mutasi $16189 \mathrm{~T}>\mathrm{C}$ memang terkait dengan diabetes. Sedangkan mutasi $16223 \mathrm{C}>\mathrm{T}$ tidak terkait dengan penyakit apapun. Analisis mutasi $73 \mathrm{~A}>\mathrm{G}$ menunjukkan keterkaitan mutasi ini dengan penuaan sel otak. Hal ini sejalan dengan usia manusia yang diambil darahnya sebagai sampel pada penelitian ini, yaitu rentang usia 6080 tahun. Dari MITOMAP juga diketahui bahwa $16189 \mathrm{~T}>\mathrm{C}, 16223 \mathrm{C}>\mathrm{T}$, dan $73 \mathrm{~A}>\mathrm{G}$ merupakan haplogrup (Tabel 1). 


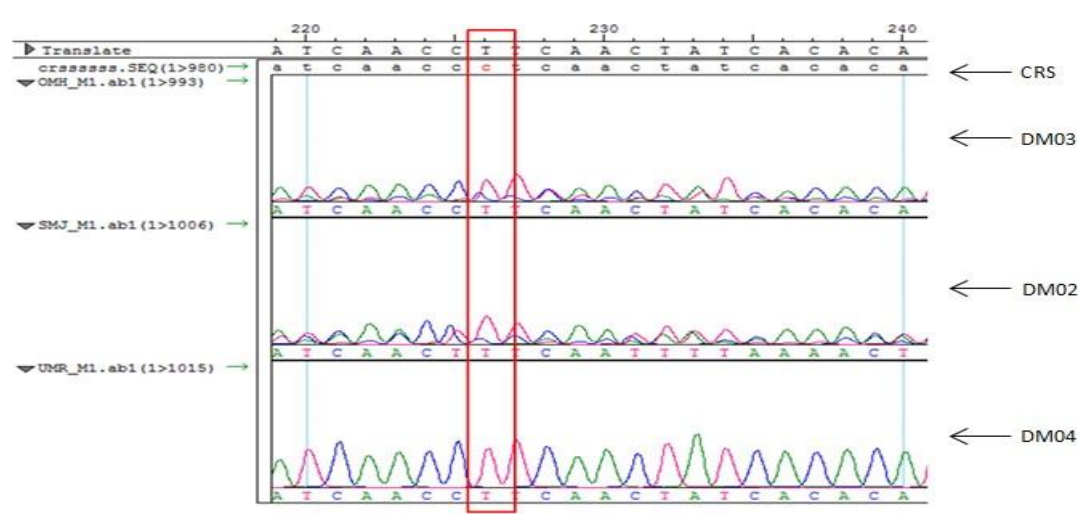

(a)

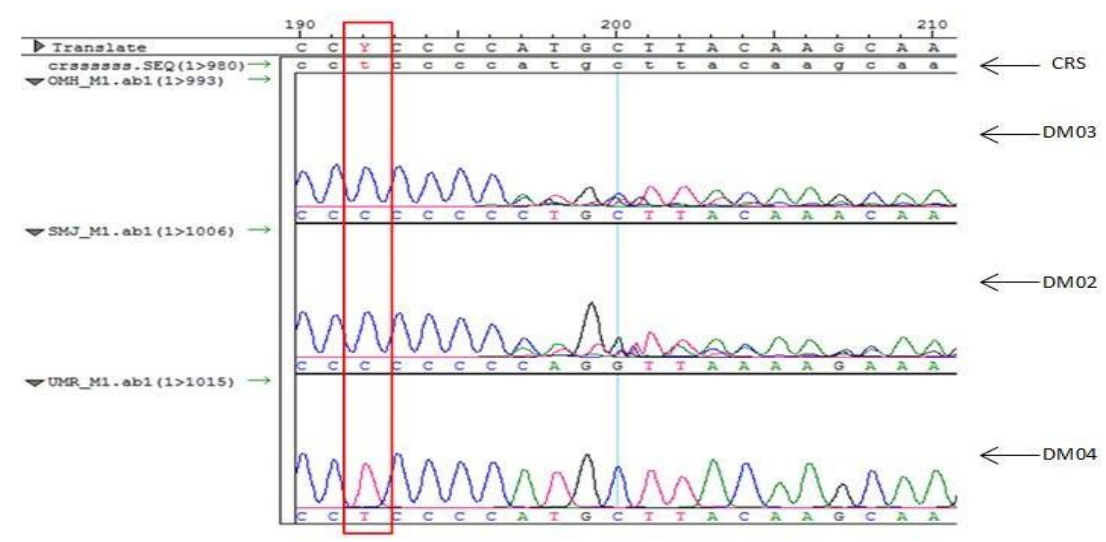

(b)

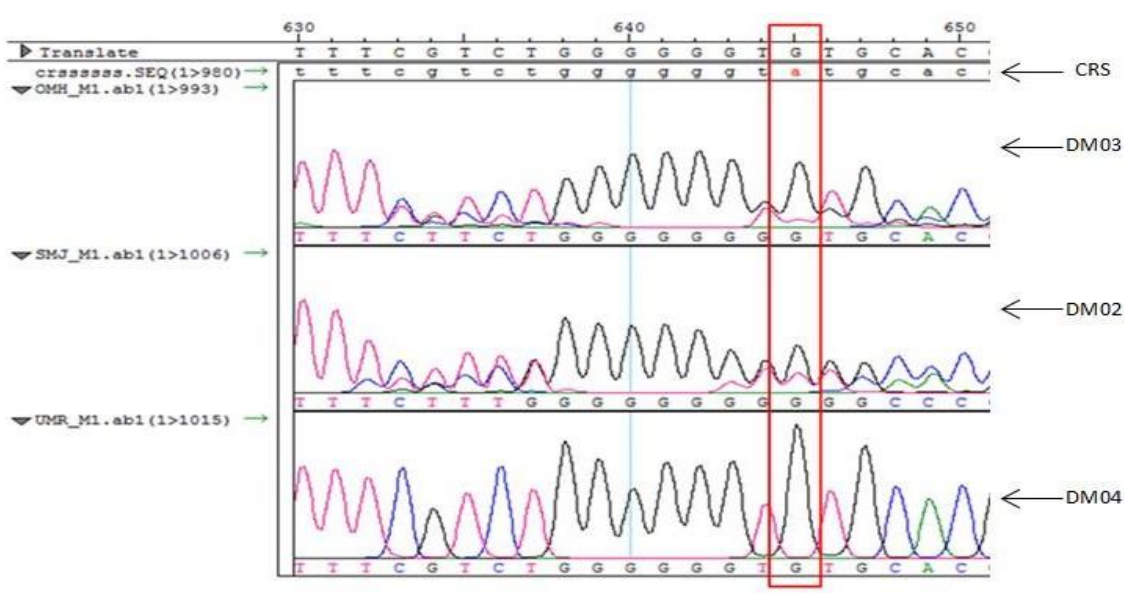

(c)

Gambar.2. (a) Mutasi 16189T >C pada sampel DM2 dan DM3; (b) Mutasi 16223C $>$ T pada sampel DM2, DM3 dan DM4; (c) Mutasi 73A>G pada sampel DM2, DM3, dan DM4 
Tabel. 1 Hasil analisa mutasi pada MITOMAP

\begin{tabular}{cll}
\hline No & \multicolumn{1}{c}{ Mutasi } & \multicolumn{1}{c}{ Keterangan dari MITOMAP } \\
\hline 1. & $16189 \mathrm{~T}>\mathrm{C}$ & Terdapat pada diabetes \\
2. & $16223 \mathrm{C}>\mathrm{T}$ & - \\
3. & $73 \mathrm{~A}>\mathrm{G}$ & Terdapat pada penuaan sel otak \\
4. & $16189 \mathrm{~T}>\mathrm{C}, 16223 \mathrm{C}>\mathrm{T}, 73 \mathrm{~A}>\mathrm{G}$ & Haplogrup \\
\hline
\end{tabular}

\section{Kesimpulan}

Dari empat sampel yang dianalisa ternyata ditemukan mutasi yang telah diketahui pada bebereapa oang menjadi ciri khas penderita diabetes. Namun, dengan penelitian ini dapat dinyatakan bahwa mutasi $16189 \mathrm{~T}>\mathrm{C}$ terkait dengan diabetes mellitus tipe II.

\section{Daftar Pustaka}

[1] Alberti KGMM, Zimmet PZ. Definition, diagnosis and classification of diabetes mellitus and its complications. Part 1: diagnosis and classification of diabetes mellitus. Provisional report of a WHO Consultation. Diabet Med. 1998. 15(7):53953. http://dx.doi.org/10.1002/(sici)10969136(199807)15:7\%3C539::aiddia668\%3E3.0.co

[2] Wulandari, Retno D, Sugiri, Yani J. Diabetes Melitus dan Permasalahannya pada Infeksi Tuberkulosis. J Respir Indo. 2013. 33(2).

[3] Olokoba AB, Obateru OA, Olokoba LB. Type 2 diabetes mellitus: a review of current trends. Oman Med J. 2012. 27(4):269-73. https://pubmed.ncbi.nlm.nih.gov/23071876

[4] Chinnery PF, Mowbray C, Patel SK, Elson JL, Sampson M, Hitman GA, et al. Mitochondrial DNA haplogroups and type 2 diabetes: a study of 897 cases and 1010 controls. J Med Genet. 2007. 44(6):e80-e80. https://pubmed.ncbi.nlm.nih.gov/17551080

[5] Sriwidodo O, Subroto T, Maksum P. Study Mutasi Titik A3243G DNA Mitokondria Penyebab Maternally Inherited Diabetes and Deafness. Majalah Ilmu Kefarmasian. 2008. :121-9.
[6] Maksum IP, Sriwidodo, Suprijana O, Natadisastra G, Nuswantara S, Noer AS. Identifikasi Mutasi Heteroplasmi A3243G DNA Mitokondria dan Studi Pewarisan Maternal pada Pasien Diabetes Melitus Tipe 2. Bionatura-Jurnal Ilmu-ilmu Hayati dan Fis. 2010. 12(2):78-85.

[7] Maksum IP, Silaen M., Suprijana O, Natadisastra G, Nuswantara S. Mutasi Baru G9053A DNA Mitokondria pada Pasien Diabetes Tipe 2 Maternal dan Katarak dan Pengaruh Mutasi terhadap Struktur Subunit ATP6. In: I-MHERE. 2011.

[8] Palit EIY, Ngili Y. Kuantifikasi dan Filogenetika Mutasi DNA. Yogyakarta: Innosain; 2016.

[9] Anderson S, Bankier AT, Barrell BG, de Bruijn MHL, Coulson AR, Drouin J, et al. Sequence and organization of the human mitochondrial genome. Nature. 1981. 290(5806):457-65.

http://dx.doi.org/10.1038/290457a0

[10] Poulton J, Brown MS, Cooper A, Marchington DR, Phillips DIW. A common mitochondrial DNA variant is associated with insulin resistance in adult life. Diabetologia. $1998 . \quad 41(1): 54-8$. http://dx.doi.org/10.1007/s001250050866

[11] Puspitaningrum R, Maududi A, Ferania M, Adiyanto C, Fitri AL, Evriyani D, et al. Analysis of Hypervariable Region 1D-Loop mtDNA Mutation in Diabetes Mellitus Type 2 Patients. Adv Sci Eng Med. 2014. 6(1):1148. http://dx.doi.org/10.1166/asem.2014.1450 
Satiyarti, R.B, et al./J. Kartika Kimia, Mei 2020, 3, (1), 1-6

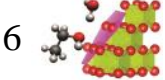

